DOI https://doi.org/10.15589/znp2020.4(482).15

УДК 378.174:004.588

\title{
THE DIGITAL TECHNOLOGY IN IT-EDUCATION: THE VIEW OF UKRAINIAN UNIVERSITY
}

\section{ЦИФРОВІ ТЕХНОЛОГІї В ІТ-ОСВІТІ: ПОГЛЯД УКРАЇНСЬКИХ УНІВЕРСИТЕТІВ}

\author{
Artem O. Yurchenko \\ a.yurchenko@fizmatsspu.sumy.ua \\ ORCID: 0000-0002-6770-186X \\ Olena V. Semenikhina \\ e.semenikhina@fizmatsspu.sumy.ua \\ ORCID: 0000-0002-3896-8151 \\ Yuliya O. Rudenko \\ yango641@ukr.net \\ ORCID: 0000-0003-3162-1216 \\ Volodymyr G. Shamonia \\ shamonawg@gmail.com \\ ORCID: 0000-0002-3201-4090
}

\section{А. О. Юрченко}

кандидат педагогічних наук, доцент кафедри інформатики

\section{О. В. Семеніхіна}

доктор педагогічних наук, професор кафедри інформатики

Ю. О. Руденко

кандидат педагогічних наук, доцент кафедри інформатики

В. Г. Шамоня

кандидат фізико-математичних наук, доцент кафедри інформатики

\section{Makarenko Sumy State Pedagogical University, Sumy \\ Сумський педагогічний університет імені А.С. Макаренка, м. Суми}

\begin{abstract}
The purpose of the publication is to analyze open educational resources for the availability of courses in the field of information technology (IT).

Methods. To achieve this goal, theoretical methods of analysis of Internet sources and educational and scientific literature were used to determine the most relevant to date educational resources and IT courses. For the quantitative analysis of the study, mathematical methods were used, which allowed to determine the share of IT courses in different characteristics and thematic areas. The analysis is based on a study of the content of ten educational platforms that provide full or partial open access to their courses.
\end{abstract}

Results. The authors of the publication described their own results of quantitative analysis of educational platforms and open resources in the field of IT. The authors of the article substantiated the contradiction between the demand of the Ukrainian society for a competitive IT specialist and the content, methods, approaches to their professional training in Ukraine. The authors see the solution of contradictions by introducing open educational courses in the training of specialists in the field of IT. The article presents the characteristics of educational platforms, as well as the classification of IT courses (programming and software development, data structures, computer (information) security and computer networks, computer graphics, web graphics, design and visualization data, web design and Internet technologies, database and SQL management systems, artificial intelligence and modern robotics, blockchain and cryptography, operating systems).

Conclusions. The authors propose to use open educational resources to organize independent work in the framework of training courses in the Ukrainian reality; for the organization of distance learning; to improve the skills of teachers. Key words: open educational resources; educational platforms; Information Technology; IT industry; IT courses.

Анотація. Метою публікації є проаналізувати відкриті освітні ресурси на наявність в них курсів в галузі інформаційних технологій (IT).

Методика. Для досягнення мети було використано теоретичні методи аналізу інтернет-джерел та навчальнонаукової літератури для визначення найбільи актуальних на сьогоднішній день освітніх ресурсів і розміщених на них курсів з ІТ. Для кількісного аналізу проведеного дослідження було використано математичні методи, щзо дали змогу визначити частку IT-курсів за різними характеристиками та тематичними напрямками. Аналіз побудовано на дослідженні контенту десяти освітніх платформ, які надають повний або частково відкритий доступ до їх курсів. Результати. Авторами публікації був зроблений опис власних результатів кількісного аналізу освітніх платформ та відкритих ресурсів у галузі IT. Автори статті обтрунтували суперечність між запитом українського 
суспільства на конкурентоспроможного IT-спеціаліста та змістом, методами, підходами до їх професійної підготовки в Україні. Автори бачать вирішення протиріч шляхом впровадження відкритих освітніх курсів у підготовку фахівиів у сфері IT.

Наукова новизна. У статті наведені характеристики освітніх платформ, а також класифікацію IT-курсів (програмування та розробка програмного забезпечення; алгоритмізація та структури даних; комп 'ютерна (інформаційна) безпека та комп 'ютерні мережі; комп'ютерна графіка, веб-графіка, дизайн та візуалізація даних; вебдизайн та інтернет-технологї; системи керування базами даних та SQL; штучний інтелект та сучасна робототехніка; блокчейн і криптографія; операційні системи), їх кількісний аналіз на таких платформах.

Практична значущість. Автори пропонують використовувати відкриті освітні ресурси для організації самостійної роботи в рамках навчальних курсів в українських реаліях; для організації дистанційного навчання; для підвищення кваліфікації вчителів.

Ключові слова: відкриті освітні ресурси; освітні платформи; інформачійні технології; IT-галузь; IT -курси.

\section{FORMULATION OF THE PROBLEM}

Today, the Ukrainian educational sector is focused on the acquisition of graduates of professional competencies and their demand in the world labor market. These and other documents are intended to promote the competitiveness of Ukraine's higher education and its integration into the European educational space. This requires not only the improvement of curricula for training specialists in order to increase the weight of professional courses and production practices, but also the study and implementation of effective foreign training experience. At the same time, the active development of information technologies influenced the establishment of the educational industry and facilitated the exchange of experience through virtual space - the emergence of open educational resources (ER) changed the traditional vision of training specialists and made it possible to get the experience not only in teaching methods of courses in various fields of knowledge, but also in familiarization with their content and awareness of the trends while presenting contemporary scientific results.

Due to the great popularity of specialties in the information technologies (IT) field in Ukraine their is a huge expansion of work in the "freelance" format with customers from abroad, with different standards for creating or presenting virtual content. Therefore the analysis of an open educational resources in the IT field on the different educational platforms becomes relevant and would contribute to resolving the contradiction between the demand of Ukrainian society for a competitive IT specialist and the established content, methods, approaches, etc., of the training for such specialists in Ukraine.

\section{ANALYSIS OF RECENT RESEARCH AND PUBLICATIONS}

By definition, UNESCO's “open educational resources are educational and scientific resources that are openly accessible or licensed, allowing their free use and modification by third parties" [1]. In Ukraine, the term "mass open online courses" or the MOOC is commonly used, which is understood as an open platform, that after the help of the recognized specialist in certain industry provides not only the free access, and online resources but also the social networks for active communication between a large number of students who self-organize their participation according to their own learning goals and prior knowledge and skills [2].

Investigation of open ER, MOOC and their implementation into educational practice is being studied by scientists from different countries. These results of scientific researchers are important for solving the contradiction: N. Aschenyuk, M. Berezan, N. Bidyuk, M. Leschenko [3] about the analysis of foreign experience in the use of mass open online courses in the international educational space, which substantiates the thesis of the spread of open courses through the development of digital humanities and the adoption in the international educational digital space humanistic pedagogy, as well as assistance to MOOC to ensure the openness of education, enrichment of the content of training, its individualization and interactivation; K. Richards-Schuster, M. Ruffolo, B. Hiltz [4] regarding the innovation of the use of MOOC, which at the same time requires the involvement of various resources, time investments, quality organizational support and awareness of the consequences of their passing by students; J. Zhang, X. Lou, H. Zhang [5] about study the correlation between the flow of attention and the performance of learning in various open ER, in particular, the authors found that understanding the patterns and dynamics of the flow of attention can positively affect the profitability of learning resources and prevent students from being overloaded; J. Zhang, H. Sziegat, K. Perris [6] about the impact of ER and MOOC on the status of elite universities in China, in particular, the strategy for the use of educational resources to improve the teaching quality and enhance the world reputation of Chinese educational institutions.

The mentioned and other scientific results in the majority cover general characteristics of open educational resources, mass open online courses. At the same time, given the trends of students' centralization in Ukrainian education, teachers who are involved in the training of IT professionals and who are now increasingly acting as transmitters of knowledge, as consultants, tutors of the individual educational 


\section{СУЧАСНИЙ СТАН I РОЗВИТОК ТЕХНОЛОГІЙ № 4ロ 2020}

trajectories of future IT specialists, face the problem of lack of scientific results that characterize at least the quantity and content of such resources in relation to particular scientific fields, in particular, the IT industry.

\section{THE PURPOSE OF THE ARTICLE}

IS to identify the quantitative characteristics of open educational resources in the IT field in order to identify ways to improve the training of IT professionals.

The goal requires solving the following tasks: 1) to identify the most popular platforms, which provide access to open educational resources, and provide them with a brief general description; 2) to investigate open ER on each of the platforms by parameters: the relative share of IT courses in general and on each platform in particular, the language of teaching, quantitative content in the thematic areas.

\section{METHODOLOGY OF RESEARCH}

The survey is based on the study of the statistical data about ten platforms, which provide access to an open ER. The preliminary analysis and generalization of research and internet sources in order to determine the popularity of educational platforms and courses on them was preceded by studying the contents of the selected resources. The method of classification was used for the conditional breakdown of IT courses on a subset in the thematic directions to their arrangement and the possibility of their quantitative analysis.

To process statistical data on the number of individual courses on open platforms used the quantitative Analysis method (method for determining the quantitative ratio of components that are part of the analyzed category) to determine the relative proportion of IT courses according to various parameters, as well as a method of comparative analysis for determination of extreme values of such quantity according to the selected parameters, their possible direct or indirect communication, Development trends, etc.

\section{RESULTS OF RESEARCH}

Over the last decade, the number of open ER project sites that provide university repositories and site projects has grown considerably. According to Class Central statistical data, a free catalog of online courses, for only 2018 year, more than 11.5 thousand were offered. Of more than 900 universities.

The objective distribution of courses indicates the popularity of the developers of industries such as "Technology" (about 20\%), "Business" (about 18\%), "Social Sciences" (about 11\%), the smallest number of courses are created in the fields of "Art and Design" $(5 \%)$ and "Mathematics" (3.1\%). Among the most popular for consumer educational content according to Class Central marked platforms: Coursera 37 million, EdX - 18 million, XuetangX - 14 million, Udacity -10 million, FutureLearn -8.7 million [5].
The generalization of the obtained results and our own impression inclined our choice to study the following ten educational platforms: Coursera [7], EdX [8], Udemy [9], MIT OpenCourse Ware [10], OpenLearn [11], Intuit [12], Prometheus [13], UoPeople [14], Open Learning Initiative [15] Open University of Maidan [16]. We conducted an analysis of ten open educational resources regarding the availability of courses in the IT industry (analyzed as of December 2019). According analysis, it can be concluded that among well-known educational platforms the most filled with different courses are foreign Coursera, EdX, MIT OpenCourse Ware, OpenLean and Intuit. The number of courses on them exceeds the value of 2.4 thousand, while in the Ukrainian Internet space the most saturated courses platform Prometeus where about 100 courses are located. Obvious is the leadership position of the resource Udemy of the number of courses in general -82943 , and on IT -35727 . According to this resource in the number of IT courses is a platform Intuit, which offers 1152 courses, then go EdX (599 courses) and MIT OpenCourseWare (351 course). At least ten courses on IT-industry offer Open Learning Initiative ( 6 courses) and OUM (4 courses). The 10-percent barrier (computer science courses to the total number of courses) underwent Udemy (43.1\%), UoPeople (28.4\%), Intuit (70.2\%), EdX (24.4\%), Prometheus (17.2\%), MIT OpenCourse Ware (14.6\%), Open Lerning Initiative $(10.7 \%)$. The smallest relative proportion of IT courses on the OpenLern platform (3.3\%).

An analysis of the teaching language offered by courses in the IT field found the following: Coursera's resource offers only 19 courses $(11.9 \%)$ in English, 1 course $(0.6 \%)$ in Ukrainian and 4th course $(2.5 \%)$ in Russian. All others, and these are 136 such courses $(85 \%)$, are offered in other languages; EdX Resource offers $90 \%$ of rates (539) in English and does not have courses in Ukrainian/Russian languages; Udemy resource offer more than half of 18758 (52.5\%) courses in English, only 4 courses $(0.01 \%)$ in Ukrainian and 340 courses $(0.95 \%)$ in Russian; MIT OpenCourseWare, OpenLearn, UoPeople, Open Learning Initiative resources offer all IT courses in English; Intuit resource has Russian language for all 1152 IT courses; Ukrainian resources Prometheus and OUM offer open ER in Ukrainian language in IT sphere according to the amount of 17 and 4 courses.

We have defined 10 generalized thematic directions according to analysis of courses names and abstracts:

Software programming and Development (TD 1) - open ER that is connected with learning different languages (e.g. Java, C\#, C++, Python, Scratch), development and testing of applications, etc. Algorithms and data Structures (TD 2) - open ER, which considers methods and methods of structuring data, algorithms and their properties. Computer security and Networks (TD 3) - in the specified direction we have been attributed to open ER, where are studied issues of information 
systems protection, cyber security, secure surfing network, as well as the setting up and use of various types of networks. Computer graphics, design and data visualization (TD 4) - open ER associated with computer Graphics study, animation, art design, relevant software, visual guidance, drawing illustrations, etc. Web design and Internet technologies (TD 5) - open ER, which give an idea of modern internet technologies and technology of web-sites development languages HTML, CSS, PHP etc. DB and SQL Management (TD 6) - open ER, which are connected with database learning, query creation, updating and management of relational databases, creating database diagrams and their modifications, access to database control systems, etc. Artificial Intelligence and Robotics (TD 7) - open ER, where are studied features of the development and possibility of using artificial intelligence, machine learning and design, creation, operation and use of robots, as well as computer systems for their Control, sensory feedback and information processing of automated technical systems, etc. Block chain and Cryptography (TD 8) - are directly attributed to the open media, which give an idea of the block chain, as well as encryption methods and mathematical methods for ensuring the confidentiality, integrity and authenticity of information. Operating systems (TD 9) - open ER view complexes of programs that perform the management of a hardware component of a computer or virtual machine and provide management of computing process, or organize the interaction with users. Other (TD 10) - This block includes all other open OR, for example, courses related to the study of specialized software of the specific scientific industry, cloud computing courses, etc.

The direction of TD1 in relation to the other most popular on Coursera platforms (54.4\% rates), EdX $(33.2 \%)$, Udemy $(42.0 \%)$, Intuit $(31.9 \%)$, Prometheus (41.2\%), Open Learning Initiative $(50.0 \%)$. The largest absolute number of courses in the direction of TD1 on Udemy (15004) and Intuit (368) resources. There is no this direction on the OUM platform.

The direction of TD2 is less popular. The relative proportion of courses in this direction ranges from $17.9 \%$ on the MIT OpenCourse Ware to $0.6 \%$ in Coursera. In a quantitative equivalent we have the leader-platform Udemy (216 courses). The second thematic direction is not presented at all on OpenLearn platforms, Open Learning Initiative, OUM.

The direction of TD3 is most represented on Udemy platform (2342 courses). Other platforms besides Open Learning Initiative, where this direction is absent, offer from 112 courses on Intuit to 1 course on Prometheus.

The direction of TD4 is the most popular on the platform Intuit (59 courses), if you reject the absolute leader - the Udemy platform (8132 courses). This direction is not presented on the Open Learning Initiative platform.

For the direction of TD5, the most relative figure is the Prometheus platform $-17.6 \%$. At the same time, in absolute numbers, it is not a leader, since the number of courses for Udemy (965 courses) follows Intuit (122 courses).

The direction of TD6 is not presented on Coursera platforms, MIT OpenCourse Ware, Prometheus, Open Learning Initiative, OUM. The largest number of kirses of this area also offer Udemy (1220 courses) and Intuit (41 course).

The direction of TD7 has relative small indicators for each platform: the largest at MIT OpenCourse Ware $(10.8 \%)$, there are no such areas of courses on Coursera, Open Learning Initiative, and OUM.

The direction of TD8 is not only poorly represented on the analyzed platforms, but also has the lowest total amount of the open ER. The direction is represented on only three EdX ( 8 courses) platforms, Udemy (312 courses) and the MIT OpenCourse Ware (10 courses).

For the direction of TD9 again the absolute leaders are Udemy platforms (1018 courses) and Intuit (56 course). 6 to 2 courses are proposed by the platforms EdX and MIT OpenCourse Ware respectively.

The direction of TD10 has a significant relative weight for EdX resources (189courses or 31.6\%), Udemy (5837 courses or $16.3 \%$ ), the MIT OpenCourse Ware (99 courses or $28.2 \%$ ), OpenLearn (16 courses or $53.3 \%$ ), Intuit (293 courses or $25.4 \%$ ).

A more detailed analysis from this directly showed popularity: for the EdX platform open, cloud technology and augmented and virtual reality; for Udemy Platform an open media learning, ecommerce, and Office software; for MIT OpenCourse Ware - an open ER on computing theory and machine interfaces; for OpenLearn and Open Learning Initiative - an open ER on the theory of Computing, e-commerce, work in the Internet; for Intuit - open ER with Office technologies, mobile technologies, hardware; for UoPeople - open ER from computer systems, cloud computing and information retrieval.

The last row of table 2 confirms the popularity of courses on programming and software development (in the direction of TD1 the generally offered 15764 courses, which is $38.6 \%$ of the total number of considered courses) and courses of computer graphics, Design and visualization of data (in the direction of TD4 is offered 8279 courses, which is $20.2 \%$ of the total number of considered courses).

\section{CONCLUSIONS}

The conducted quantitative analysis confirms the popularity of open education: there is currently a large number of platforms that provide access to open educational resources from different fields of knowledge.

The mass proportion of courses on the IT-industry in open educational resources with respect to all offered is quite extensive: Intuit courses of computer science occupy $70 \%$ of all courses, at Udemy $-43 \%$, UoPeople $28 \%, \mathrm{EdX}-24 \%$. 


\section{СУЧАСНИЙ СТАН I РОЗВИТОК ТЕХНОЛОГІЙ № 4n 2020}

A large proportion of courses is offered not only in programming and software development, although these rates have the highest relative weight $(38.6 \%$ of the rates discussed), but also from the directions related to the study of specialized software specific scientific field (mathematics, physics, biology, finances, etc.), with the methods of processing multi-format information content, with cloud computing, etc. There are comparatively many such courses regarding algorithms and data structuring, computer security or network technologies. This suggests that the modern youth has a variety of requests, which are met by copyright courses of leading teachers of the world.

Among the ways to improve the professional training of specialists of IT-industry due to the open ER we note: organization of independent work within separate courses of training plan; use of open non-profit ER for organization of remote or correspondence training; passing open ER as refresher courses; personal research on open ER; Possibility and expediency of copyright methods dissemination in the development of their own courses and promoting them on open platforms.

\section{REFERENCES}

[1] Sophie Touzé. (2014). Open Educational Resources in France: Overview, Perspectives and Recommendations. UNESCO Institute for Information Technologies in Education [in English].

[2] McAuley A., Stewart B., Siemens G., Cormier D. (2010). The MOOC Model for Digital Practice. Created through funding received by the University of Prince Edward Island through the Social Sciences and Humanities Research Council's "Knowledge Synthesis Grants on the Digital Economy". [in English].

[3] Avshenyuk N., Berezan V., Bidyuk N., Leshchenko M. (2018). Foreign Experience And Ukrainian Realities Of Mass Open Online Courses Use In International Education Area. Information Technologies and Learning Tools. No 68(6). pp. $262-272$. doi: http://dx.doi.org/10.33407/itlt.v68i6.2407 [in English].

[4] Richards-Schuster K., Ruffolo M., Hiltz B. (2019). Innovating Practices to Prepare Students for Graduate School: Lessons From a Social Work MOOC. Journal of Social Work Education. No55(2). pp. 314-326. doi: 10.1080/10437797.2018.1548986 [in English].

[5] Zhang J., Lou X., Zhang H., Zhang J. (2019). Modeling collective attention in online and flexible learning environments. Distance Education. No 40(2). pp. 278-301. doi: 10.1080/01587919.2019.1600368 [in English].

[6] Zhang J., Sziegat H., Perris K., Zhou Ch. (2019). More than access: MOOCs and changes in Chinese higher education. Learning, Media and Technology. No 44(2). pp. 108-123. doi: 10.1080/17439884.2019.1602541 [in English].

[7] Coursera | Online Courses - Credentials From Top Educators. Retrieved from: https://www.coursera.org/. [in English].

[8] edX | Online courses from the world's best universities. Retrieved from: www.edx.org. [in English].

[9] Online Courses - Anytime, Anywhere | Udemy. Retrieved from: https://www.udemy.com/. [in English].

[10] MIT OpenCourseWare | Free Online Course Materials. Retrieved from: https://ocw.mit.edu/. [in English].

[11] Free courses - OpenLearn - Open University. Retrieved from: https://www.open.edu/openlearn/free-courses. [in English].

[12] National Open University "Intuit”. Retrieved from: https://www.intuit.ru/. [in Russian].

[13] Prometheus - mass free online courses. Retrieved from: https://prometheus.org.ua. [in Ukrainian].

[14] University of the People Accredited Online American University | University of the People. Retrieved from: https://www. uopeople.edu/. [in English].

[15] Open Learning Initiative - OLI. Retrieved from: https://oli.cmu.edu/. [in English].

[16] Open University of Maidan. Civic Education in Ukraine. Retrieved from: https://vum.org.ua/. [in Ukrainian]. 